\title{
LENGVĄJA ATLETIKA UŽSIIMANČIŲ PAAUGLIŲ ASMENYBĖS NERIMO IR PSICHINĖS BŪSENOS PRIEŠ VARŽYBAS YPATUMAI
}

\author{
Skaistė Laskienė, Akvilė Gedvilaitė-Moan \\ Lietuvos kūno kultūros akademija, Kaunas, Lietuva
}

Skaistė Laskienė. Docentė humanitarinių mokslų (filosofijos) daktarė. Lietuvos kūno kultūros akademijos Kinantropologijos ir sporto raidos katedros vedèja. Mokslinių tyrimų kryptis — kinantropologijos kaip sporto mokslo humanitarinès paradigmos galimybès.

\section{SANTRAUKA}

Nerimo prieš varžybas tema yra labai aktuali ne tik profesionaliems sportininkams, bet ir fizinius, emocinius, socialinius pokyčius išgyvenantiems paaugliams, kurie aktyviai sportuoja, dalyvauja varžybose. Tyrimo objektu pasirinkti lengvaja atletika užsiimančiu paaugliu (atrankos kriterijus - 12-18 m. jaunuoliai) asmenybès nerimo ir psichinès būsenos prieš varžybas ypatumai. Kelta hipotezè, kad asmenybès nerimas ir psichinès būsenos prieš varžybas komponentai (fizinis, emocinis ir kognityvusis) statistiškai patikimai skiriasi priklausomai nuo lyties.

Jaunuju sportininku asmenybès nerimo lygis tirtas Dž. Teiloro klausimynu. V. A. Aleksejevo priešvaržybinès psichinès būsenos ¿̇vertinimo klausimynu nustatyti vyraujantys psichinès būsenos komponentai tarp paaugliu.

Išanalizavus lengvaja atletika užsiimančiu paaugliu asmenybès nerimo lygio rezultatus, patikimo skirtumo tarp lyčiu neaptikta $(p>0,05)$.

Ištyrus lengvaja atletika užsiimančiu paaugliu psichinès büsenos prieš varžybas pobüdi (fizini, emocini bei kognityvuji komponentus), nustatytas statistiškai patikimas merginu ir vaikinu priešvaržybinès psichinès büsenos rodikliu skirtumas $(p<0,05)$. Taip pat paaiškejjo, kad nepriklausomai nuo lyties vyrauja kognityviojo (mintinio) psichinès büsenos komponento raiška.

Palyginome ir lengvaja atletika užsiimančiu paaugliu asmenybès nerimo ir psichinès būsenos prieš varžybas ypatumu priklausomumq nuo lyties. Paaiškèjo, kad lengvaja atletika užsiimančiu paangliu priešvaržybinès psichinès būsenos ir asmenybès nerimo raiškos tyrimo rezultatai, gauti ìvertinus kiekvieno tiriamojo psichinę büsenq individualiai pagal abi metodikas, statistiškai patikimai skiriasi lyties aspektu $(p<0,05)$.

Polinkis jausti neadekvatu nerima per varžybas trukdo sportininkams. Esant aukštam nerimo lygiui, dažnai nepasiekiama geru sportiniu rezultatu, todèl tokiems sportininkams reikia skirti ypatinga dèmesi. Kiekvieno trenerio ir sporto psichologo pareiga padèti sportininkui nugalèti arba nors kiek prislopinti tokiq büsenq ir jos neigiama poveiki sportiniams rezultatams.

Raktažodžiai: lengvoji atletika, asmenybès nerimas, psichinè priešvaržybinè būsena.

\section{IVADAS}

$\mathrm{T}$ yrimais nustatyta, kad teigiamas ryšys sieja mokymosi pažangumą, mokinių savigarbą ir nerimastingumą (Gage, Berliner, 1994). Kuo labiau žmogų apėmęs nerimas, tuo prasčiau jam gali sektis iqvairioje veikloje — mokantis, dirbant, bendraujant, sportuojant.

Nerimo prieš varžybas tema susidomèta tikrai anksti, sukurta nemažai teorijų, testų, metodų, tiriančių sportuojančių žmonių būseną prieš varžybas. H. K. Hall ir A. W. Kerr (1997) mini mokslinius darbus, kurių tikslas - tirti ir atrasti

individualius skirtumus ir situacinius kintamuosius, darančius poveiki priešvaržybiniam nerimui (Gould et al., 1984; Krane, Williams, 1994). Visgi šie tyrimai visiškai nepaise daug svarbesnių teoriniu prielaidų: kodèl nurodyti kintamieji gali iš anksto nuteikti sportininkus dideliam nerimui prieš varžybas. Vèlesni sportinio nerimo tyrimai èmé nagrinèti laikinas priežastis, kurios veikia sportininkų psichinę būseną prieš varžybas. Dauguma tyrèjų sutelkè dèmesi $\mathfrak{i}$ individualius sportininkų asmenybès skirtumus kognityviuoju psichinès 
būsenos aspektu, tikèdamiesi rasti būdų mažinti nerimą.

Lietuvoje šia tema labiau imta domètis neseniai, tačiau tyrimų kaskart gausėja: D. Jankauskas (2004) magistro baigiamuoju darbu tyrè streso, kylančio prieš varžybas, ypatumus; T. Skučas (2003) — aptare didelio meistriškumo stalo tenisininku priešvaržybinès būsenos ypatumus; A. Jurkšas (2002) - lengvaatlečių (metikų) psichologinio rengimo reikšmę priešvaržybinèms jų būsenoms valdyti; J. Barzinskienè (1997) — analizavo krepšininkiu priešvaržybinès būsenos ypatumus.

Paauglystėje dažniausiai išryškejja pagrindinès polinkių ir interesų kryptys. Sportas kaip pasirinktoji veikla yra kryptingas, be to, sportiné veikla gali teigiamai veikti sportuojančių asmenų savigarbą: jie labiau pasitiki savimi ir teigiamiau vertina save. Tai nustate daugelis mokslininku (Kamal et al., 1995; Marsh et al., 1995; Стамбулова, 1999). Kiekviena išbandymų situacija sportininkui virsta akistata su įvairiais išoriniais (varžybų aplinka, priešininkai, žiūrovai) ir vidiniais (itampa, susijaudinimas, džiaugsmas, baimė) poveikiais. Šie poveikiai ir sukelia psichologinę reakciją, kuri arba pagerina, arba pablogina sportininko pasirodymą (Schmolinsky, 2000).

Y. Ommundsen ir B. H. Pedersen (1999) teigia, kad dauguma paauglių patiria nerimą dalyvaudami varžybose. Turint galvoje, kad sporto pratybos pritraukia labai daug vaiku ir paauglių, susiduriama su tokia problema: sportinis nerimas sukelia psichologinę disfunkciją, norą atsisakyti sporto pratybų. Taigi i nerimą sporte reikia atkreipti ypatingą dèmesi. Tirti vaikus ir paauglius labai svarbu norint sudaryti strategijas, leidžiančias nugalèti nerimą, kuris sukelia stresą sportuojant. Atlikta daugybė nerimo poveikio sportiniams rezultatams tyrimų. Mokslininkai R. Martens ir kt. (1990) nustate, kad priešvaržybinis nerimas kamuoja individualiojo sporto mègejjus labiau negu grupinio, M. Humara (1999) — kad nekontaktiniu individualiujų šakų sportininkų nerimo lygis žemesnis negu kontaktinių individualiuju. Todèl ir pasirinkome tirti lengvaatlečius - individualiosios šakos sportininkus paauglius.

Tyrimo aktualumas susijęs su teiginiu, kad paauglystes laikotarpis yra unikalus ir aktyviai sportuojantys paaugliai nuolat patiria jauduli ir nerimą prieš varžybas. Todèl būtina stebèti, kad nerimas netaptų dezadaptyvaus elgesio pagrindu. Labai svarbu nustatyti reakcijas, kurios griauna sportininko pasitikèjimą savimi, o psichinè būse- na prieš varžybas, nerimas, yra labai paplitusi ir diskutuojama sporto problema.

Nemaža dalis tyrimų rodo, kad daugelis treneriu ir sportininku gana gerai suvokia sporto psichologijos reikšmę, galimybes ir būtinumą sportinio rengimosi metu. Sportininkams ir treneriams svarbu gauti psichologinę pagalbą ir didinti savo psichologinę kompetenciją. Viena svarbiausių sportininko rengimo krypčių, kuriai dažnai skiriama nepelnytai mažai dėmesio, yra psichologinis rengimas. Be psichologinio rengimo šiandien neimanoma pasiekti gerų sportinių rezultatų, atsigauti po traumų, atsikratyti nepageidaujamo, kartais destruktyvaus nerimo jausmo prieš varžybas ir kasdieniame gyvenime. Psichologinis trenerių ir sportininkų rengimas yra ginklas einant pergalès link. Todèl daugeliui sportininkų, jų trenerių rūpi išmokti ir susidoroti su priešvaržybiniu nerimu. Būdai, galintys sumažinti nerimą, leidžia sportininkui atsipalaiduoti, valdyti savo veiksmus varžybų metu.

A. V. Aleksejevas (Алексеев, 1995), jau trisdešimt metų analizuojantis sportininkų psichinès būsenos valdymo problemas, teigia, kad pasitikintis savimi, mokantis savarankiškai valdyti savo psichofizinę būseną ir techniką sportininkas nesibaimins, nejaus nerimo dèl sportinio rezultato. Kadangi sportinè veikla vyksta sunkiomis pratybu ir varžybu sąlygomis, tai tokiai veiklai būtinas ypatingas sportininko psichikos stabilumas. Sportinis meistriškumas daug priklauso nuo to, kaip išugdytos sportininko psichinès savybès, kaip jis valdo savo emocines būsenas.

Ankstesniuose mokslininkų darbuose (Martens et al., 1990) teigiama, kad priešvaržybini nerimą galima skirstyti i kognityvuji ir somatini (fizini). Kognityvusis nerimas yra mintinis nerimo komponentas, kuri sukelia neigiami sportininko sèkmès lūkesčiai. I. Morris ir kt. (1981) nuomone, kognityvusis nerimas apibūdinamas kaip sąmoningas nemalonaus jausmo apie save suvokimas arba suvokimas išorinių paskatų, baimès, sunkumu regimajame lauke dèl trukdančių matomų vaizdų.

Somatinis (fizinis) nerimas atsiranda dèl suvokto fizinio susijaudinimo, jis pasireiškia širdies permušimais, oro trūkumu, delnu prakaitavimu, „drugeliais pilve“ ir raumenu isitempimu (Martens et al., 1990).

Tyrimo tikslas - nustatyti lengvaja atletika užsiimančių paauglių asmenybès nerimo ir priešvaržybinès psichinès būsenos ypatumus.

Tyrimu kèlème tokius uždavinius:

1. Nustatyti lengvaja atletika užsiimančių paauglių asmenybès nerimo lygi. 
2. Ištirti ir nustatyti jų psichinès būsenos prieš varžybas pobūdi (fizini, emocinį ir kognityvuji komponentus).

3. Palyginti lengvaja atletika užsiimančių paaugliu asmenybès nerimo ir psichinès būsenos prieš varžybas ypatumų priklausomumą nuo lyties.

\section{TYRIMO METODAI}

Pasirinkta patogioji imtis, atrankos kriterijus - 12-18 metų paaugliai (amžiaus ribos pagal D. G. Meyers (2000)), užsiimantys lengvaja atletika Lietuvos kūno kultūros akademijos manieže. Iš viso apklausta 60 paauglių: 35 vaikinai ir 25 merginos, visi jau dalyvaujantys varžybose ir dauguma iš jų užèmę prizines vietas. Tiriamuju specializacija nebuvo svarbi.

Tiriant buvo naudojamas V. A. Aleksejevo testas-klausimynas, skirtas sportininkų būsenai prieš varžybas nustatyti, ir Dž. Teiloro asmenybès nerimo lygio nustatymo metodika, adaptuota $1966 \mathrm{~m}$. profesoriaus T. A. Nemčino (Волков, 2002). Abi šios metodikos aprobuotos Sporto pedagogikos ir psichologijos katedroje.

V. A. Aleksejevo metodiką sudaro 30 klausimų. Šiuo klausimynu galima nustatyti sportininko subjektyvią būseną, pojūčius, jausmus ir mintis, atsirandančius prieš varžybas pagal savo būsenos prieš varžybas vertinimus. Klausimynas sudarytas remiantis sporto psichologijos priimtu psichinès būsenos apibūdinimu, grindžiamu trimis būsenos komponentais: F - fiziniu (kūno-elgsenos) klausimų numeriai: 1, 4, 7, 10, 13, 16, 19, 22, 25, 28; E - emociniu (energetiniu) - 2, 5, 8, 11, 14, 17, 20, 23, 26, 29; K - kognityviuoju (mintiniu) - 3, 6, 9, 12, 15, 18, 21, 24, 27, 30 .

T. A. Nemčino adaptuotą Dž. Teiloro asmenybès nerimo lygio nustatymo metodiką sudaro 50 teiginių, i kuriuos ilgai negalvodami respondentai turejo atsakyti „taip“ arba „ne“. Klausimu pobūdis aprèpia psichologinę būseną kasdienėmis, iprastomis situacijomis. Pagal šią metodiką galima išskirti penkis nerimo lygius:
1) labai aukštą,
2) aukšta,
3) vidutini, turinti tendenciją didèti,
4) vidutini, turintį tendenciją mažèti,
5) žemą.

Duomenims susumuoti ir rezultatams analizuoti buvo naudotasi SPSS. 13 statistinès informacijos apdorojimo programiniu paketu bei Excel programa. Abiejų minètų metodikų gautų rezultatų skirtumo patikimumas buvo apskaičiuojamas pagal chi kvadrato $\left(\chi^{2}\right)$ kriterijų. Pasirinktas patikimumo lygmuo $\alpha=0,05$.

\section{REZULTATAI}

Paauglių merginų tyrimo rezultatai rodo, kad vyrauja vidutinis, turintis tendenciją didèti, nerimo lygis - jis nustatytas net $56 \%$ apklaustujų. Vidutinis, turintis tendenciją mažèti, nerimo lygis buvo antras pagal raišką - $28 \%$ merginų. Aukšto ir žemo nerimo lygi patiriančių merginu buvo mažuma - atitinkamai 4 ir $12 \%$. Nè vienos tiriamosios nerimo lygio raiška nebuvo labai aukšta (1 lent.).

Vaikinų, užsiimančių lengvaja atletika, atsakymu rezultatai rodo, kad vyraujantys nerimo raiškos lygiai yra keli. Vidutinis, turintis tendencija didèti arba mažèti, pasiskirstė vienodai — apie $38 \%$ kiekvieno lygio tiriamujų. Aukštą ir žemą asmenybès nerimo lygi patiriančių vaikinų buvo mažuma - atitinkamai 11 ir 14\%. Labai aukšto nerimo lygio raiška visai nebūdinga tiriamiems vaikinams (1 lent.).

V. A. Aleksejevo metodika (Волков, 2002) leido nustatyti sportuojančio paauglio vyraujanti priešvaržybinès psichinès būsenos komponentą (fizini, emocini, kognityvuji). Tyrimo rezultatai rodo, kad nepriklausomai nuo lyties vyrauja kognityvusis (mintinis) psichinès būsenos komponentas tiek tarp merginu $-76 \%$, tiek tarp vaikinu $-55 \%$. Pasak S. R. Bray ir kt. (2000), kognityvusis nerimas kyla dèl jaudulio ir neigiamų minčiu, jis prasideda mintyse apie artejjančio pasirodymo tokius ivertinimo aspektus, kaip pasirodymo lūkesčiai, gebejjimų ir įvertinimo grèsmès suvokimas.

Vaikinų psichinès būsenos emocinio komponento raiška yra didesnè negu merginu -31 ir $16 \%$. Emocinis nerimas yra žmogaus santykio su savimi ir kintančia aplinka išgyvenimo atspindys, tai - konkretus jausmo išgyvenimo reiškimasis (pyktis, baimè, džiaugsmas) (Sporto terminu žodynas, 2002).

Fizinis psichinès būsenos komponentas tarp paauglių, užsiimančių lengvaja atletika, pasireiškẻ mažiausiai tiek vaikinų (14\%), tiek merginų ( $8 \%)$ grupejje. Fizinis psichinès priešvaržybinès būsenos komponentas rodo fiziologinio susijaudinimo pokyčius, kurie kyla dèl tokių veiksnių kaip stebintys žiūrovai ar oficialūs asmenys (Bray et al., 2000).

Remiantis tyrimo rezultatais (2 lent.), 95\% patikimumu galima teigti (pasirinktas reikšmingumo lygis $\alpha=0,05$ ), kad aptiktas statistiškai reikšmingas skirtumas tarp merginų ir vaikinu 


\begin{tabular}{|c|c|c|c|c|c|c|c|}
\hline Nerimo lygis & Labai aukštas & Aukštas & $\begin{array}{l}\text { Vidutinis, tu- } \\
\text { rịs tendenciją } \\
\text { didèti }\end{array}$ & $\begin{array}{l}\text { Vidutinis, tu- } \\
\text { rịs tendenciją } \\
\text { mažèti }\end{array}$ & Žemas & $\mathrm{p}$ & $\alpha$ \\
\hline Merginos & 0 & 1 & 14 & 7 & 3 & \multirow{2}{*}{0,116} & \multirow{2}{*}{$>0,05$} \\
\hline Vaikinai & 0 & 4 & 13 & 13 & 5 & & \\
\hline
\end{tabular}

\begin{tabular}{|c|c|c|c|c|c|c|}
\hline Tiriamieji & Fizinis & Emocinis & Kognityvusis & $\mathrm{p}$ & $\alpha$ & $\begin{array}{l}2 \text { lentelè. Tiriamųjų skirsti- } \\
\text { nys pagal vyraujantị psichi- } \\
\text { nès būsenos prieš varžybas }\end{array}$ \\
\hline Vaikinai & 5 & 11 & 19 & \multirow{2}{*}{0,0002} & \multirow{2}{*}{$<0,05$} & komponentą \\
\hline Merginos & 2 & 4 & 19 & & & \\
\hline
\end{tabular}

priešvaržybinès psichinès būsenos $\left(\chi^{2}=16,75\right.$; $\mathrm{p}=0,0002)$. Pasitvirtino hipotezè, kad priešvaržybinès psichinès būsenos ypatumai statistiškai patikimai skiriasi lyties aspektu.

\section{REZULTATUQ APTARIMAS}

Nerimas - dažnas sportininko palydovas. Jis pasireiškia ne tik jausmuose, mintyse ir veiksmuose, bet ir išoriškai - tai būtų fizinè psichinès būsenos komponento raiška. Šio psichinès būsenos komponento raiška yra mažiausiai būdinga lengvaja atletika užsiimantiems paaugliams (12\% tiriamujuc), kurių asmenybès nerimo lygis buvo žemas arba vidutinis (1 pav.).

Emocinis psichinès būsenos komponentas vaikinų priešvaržybinę psichologinę būseną labiau atitiko negu merginų. Vaikinų emocinio psichologinès būsenos komponento rezultatų stulpelyje (1 pav.) matyti visu galimų asmenybès nerimo lygiu, išskyrus labai aukštą, ivertinimą. Merginų, kurioms būdingas šis psichinès būsenos prieš varžybas komponentas, asmenybès nerimo lygis yra vidutinis. Taigi $25 \%$ tiriamuju priešvaržybiniam nerimui būdinga emocinio komponento raiška.
Kognityviojo psichinès būsenos komponento raiška vyrauja nepriklausomai nuo lyties. Šis komponentas pasireiškia keturiais asmenybès nerimo lygiais (išskyrus labai aukštą). Taip pat nustatyta, kad aukšto lygio nerima jaučiantys paaugliai lengvaatlečiai prieš varžybas nejautė fizinio nerimo - jaudinimasis reikšdavosi kaip kognityvusis arba emocinis psichinès būsenos komponentas.

Galima teigti, kad dauguma apklaustų tiriamuju — ir merginų, ir vaikinu — jaučia vidutinio lygio nerima, turinti tendenciją didèti. Taigi vyrauja kognityvusis mintinis psichinès būsenos komponentas. Toks rezultatas leidžia daryti išvada, kad reikètų susirūpinti jaunujų sportininkų psichine būsena, taisyti jų mąstymo klaidas, padèti išmokti valdyti savo mintis ir jausmus.

Apskaičiavus tyrimo rezultatus ir patikrinus, ar gautas patikimas skirtumas lyties aspektu, nustatyti individualūs kiekvieno paauglio nerimo lygiai ir vyraujantys prieš varžybas psichinès būsenos komponentai. Excel programiniu paketu apdoroti duomenys pasiskirstè taip, kaip pavaizduota 1 paveiksle. Tai leido apskaičiuoti abiejų lyčiu atsakymu vidurkius, o jiems palyginti naudotas $c h i$ kvadrato $\left(\chi^{2}\right)$ kriterijus.

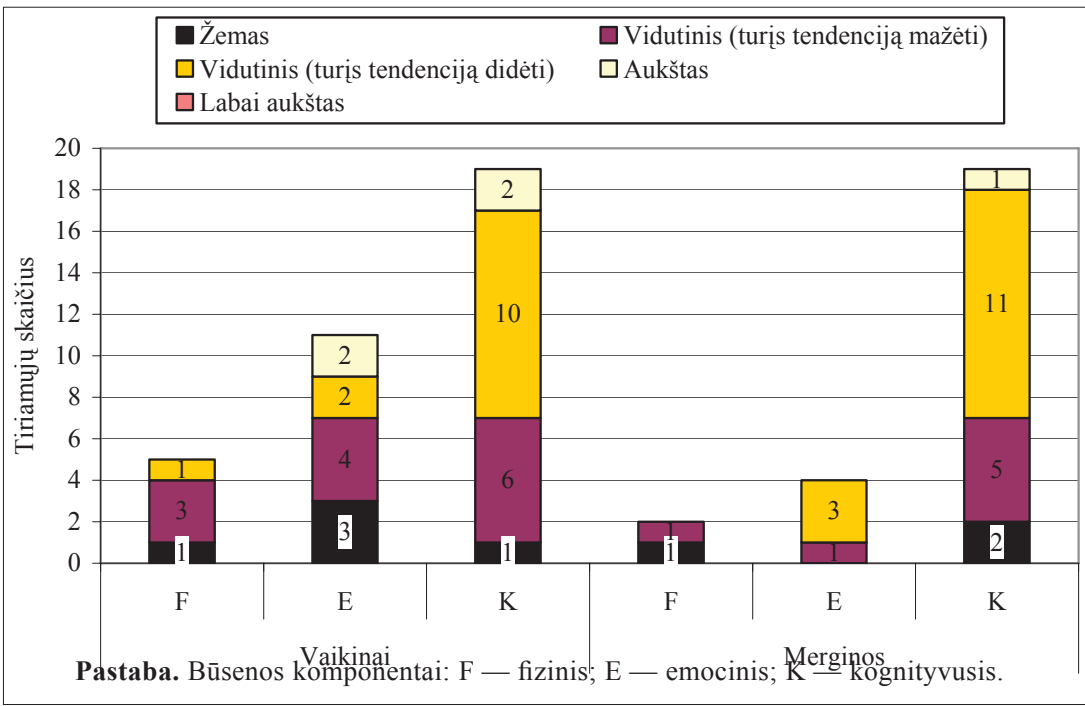

1 pav. Nerimo lygių skirstinys lyties aspektu 
2 pav. Savo judesių koordinacijos įvertinimo skirstinys
3 pav. Pasitikèjimo savimi prieš varžybas ivertinimo skirstinys
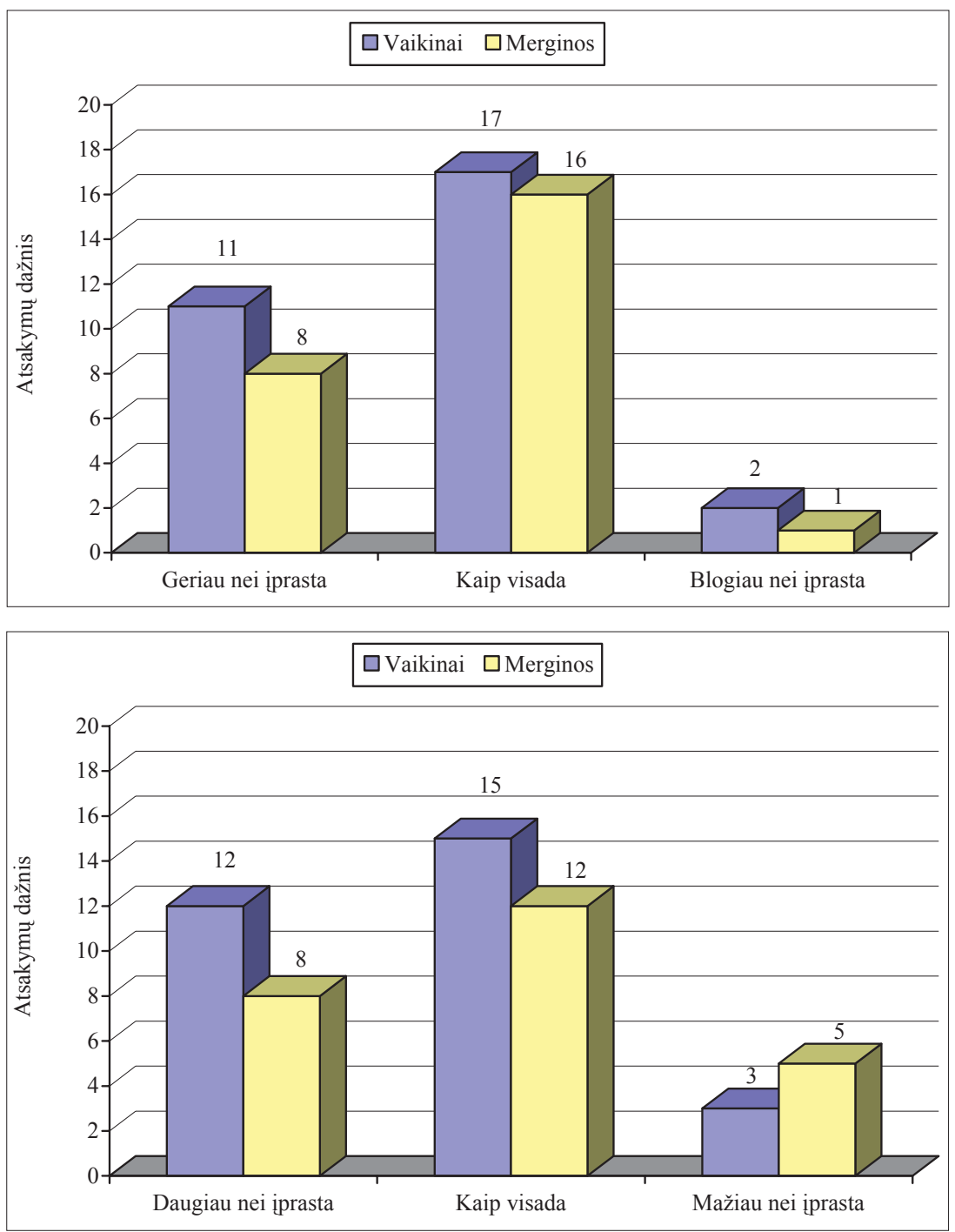

Kadangi V. A. Aleksejevo priešvaržybinès psichinès būsenos komponentų nustatymo metodika remiasi subjektyvia tiriamojo nuomone apie savo psichinę būklę, kitaip tariant - savęs vertinimą, nuspręsta nuodugniau ištirti kai kuriuos neatsitiktinai pasirinktus respondentų atsakymus į tam tikrus klausimus. Klausimyną sudaro 30 klausimų, iš kuriu 10 priklauso kognityviojo, 10 - emocinio ir 10 - fizinio priešvaržybinès psichinès būsenos komponento skalėms.

Fizini priešvaržybinès būsenos komponentą geriausiai nusako klausimai apie judesius, judesiu koordinaciją, bendrą organizmo, širdies, skrandžio veikla.

Buvo pasirinktas klausimas apie judesiu koordinacijos įvertinimą prieš varžybas. Gauti pasirinktojo klausimo ịvertinimo rezultatai (2 pav.) rodo, kad $56,7 \%$ vaikinų ir $64 \%$ merginų savo judesiu koordinaciją prieš varžybas vertina kaip ir iprasta. Manančių, kad judesių koordinacija yra geresnè negu iprastai buvo šiek tiek mažiau $36,7 \%$ vaikinų ir $32 \%$ merginų. Blogiau nei iprastai savo judesių koordinaciją vertino mažiausia tiriamujų dalis - 6,7\% vaikinu ir 4\% merginų.

R. J. Kirby ir J. Liu (1999) tyrimais nustate, kad lengvaatlečiai mažiau pasitiki savimi, o vyraujantis priešvaržybinès psichinès būsenos komponentas tarp ju yra fizinis (somatinis) - kitaip negu krepšininkų. M. Humara (1999) nuomone, tokia tendencija išryškèja dèl to, kad komandinių šakų sportininkams tenka mažesnė atsakomybè negu individualiuju.

Emocini priešvaržybinès psichinès būsenos komponentą geriausiai apibūdina atsakymai $\mathfrak{i}$ klausimus apie savo nuotaikos, emocinès būsenos, noro dalyvauti varžybose, tarpusavio santykių su treneriais, artimaisiais, aplinkiniais, pasitikejimo savimi, ramybès vertinimą.

Kitas pasirinktas klausimas - apie pasitikèjimą savimi prieš varžybas. Gauti i̇vertinimo rezultatai (3 pav.) rodo, kad 50\% vaikinų ir $48 \%$ merginuc pasitiki savimi prieš varžybas kaip iprasta. Pasitikinčių savimi daugiau nei iprasta vaikinų $10 \%$, merginu $-20 \%$. Mažiau pasitikinčiu savimi 

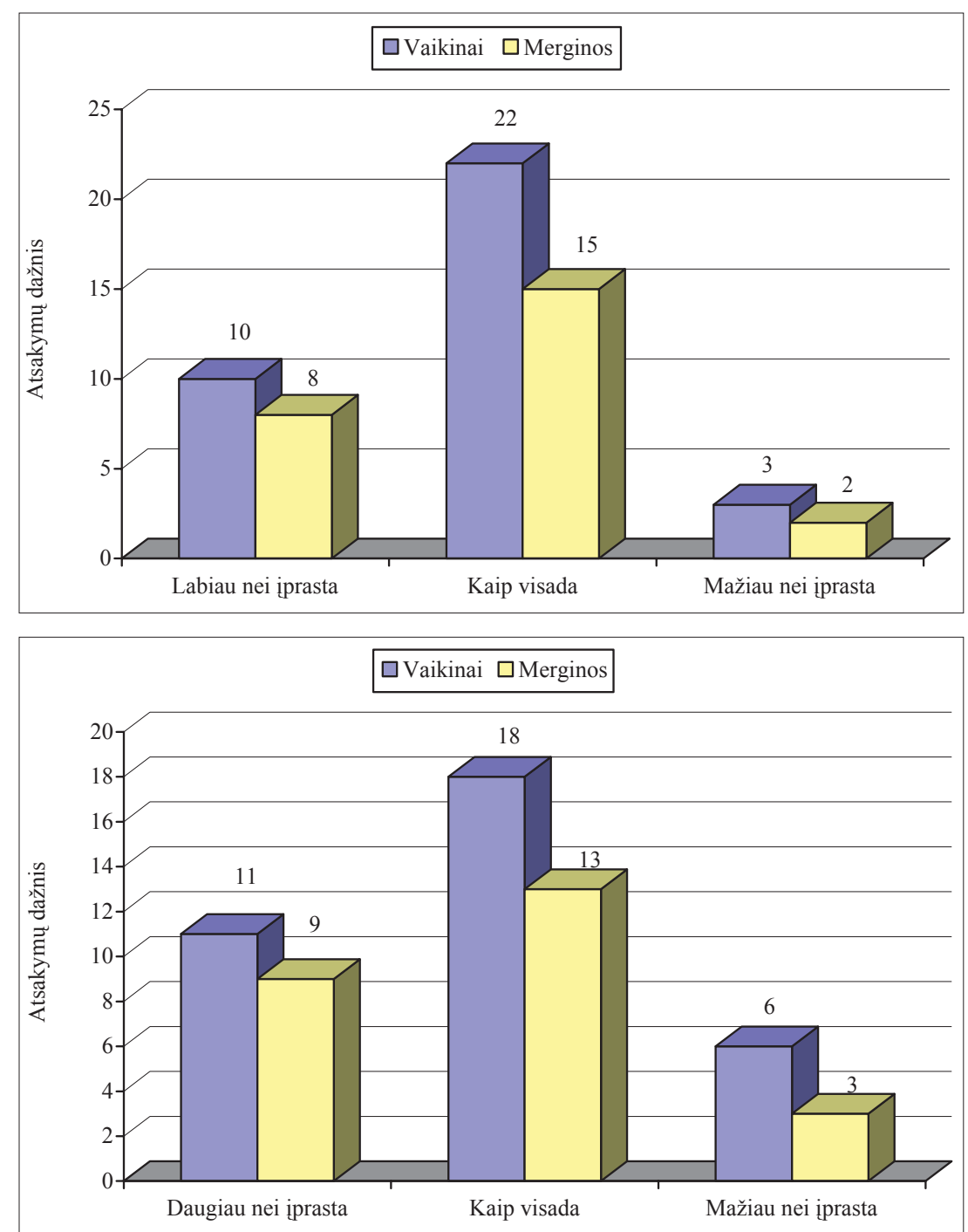

4 pav. Savo galimybės laimėti būsimas varžybas įvertinimo skirstinys
5 pav. Savo minčių apie varžovus intensyvumo įvertinimo skirstinys merginų buvo 32\%, t. y. kur kas mažiau negu vaikinu $(40 \%)$.

Emocinis priešvaržybinès psichinès būsenos komponentas mokslinèje literatūroje dar vadinamas pasitikèjimo savimi. J. D. Perry ir J. M. Williams (1998) manymu, patyrę sportininkai (buvo tirti gimnastai) turi daugiau pasitikejjimo savimi. D. Gould ir kt. (1984) savo tyrimais grindžia teigini, kad pasitikèjimą savimi labiausiai lemia sportininko suvokimas, turi jis ar neturi gebejimu pasiekti norimą rezultatą ar pergalę. M. Humara (1999) teigia, kad pasitikejjimas savimi sportininką gali saugoti nuo kognityviojo nerimo.

Kognityvuji priešvaržybinès psichinès būsenos komponentą geriausiai nusako atsakymai i klausimus apie taktinių varžybų veiksmų, būsimo rezultato, galimybės laimèti ar pralaimèti įsivaizdavimą, dèmesingumą, mintis apie tai, ko iš sportininko tikimasi.

Atsakymai i pasirinktą klausimą apie galimybę laimèti būsimose varžybose (4 pav.) rodo, kad vaikinai, vertinantys savo galimybę laimèti būsimose varžybose ,kaip visada“, sudaro 62,8\%, o taip manančiuc merginų yra $60 \%$. Labiau nei iprasta savo galimybę laimèti vertina $28,5 \%$ vaikinu ir 32\% merginu. Savo galimybe laimèti būsimąsias varžybas mažai tiki $8,5 \%$ vaikinų ir $8 \%$ merginų. Tokios atsakymų tendencijos tikrai džiugina. Sportiniai rezultatai, regis, pagerètų, jeigu tiriamujuc, vertinančių savo galimybę ,labiau nei iprasta“ laimèti varžybose, būtų daugiau.

D. Gould ir kt. (1984) teigimu, kognityvusis nerimas arba priešvaržybinès psichinès būsenos kognityvusis komponentas pasireiškia mažiau, kai sportininkas yra labiau patyręs. Tai įrode tenisininkų tyrimas. Pradedančiujuc kognityvusis nerimas buvo labai ryškus, palyginti su ilgesnị laiką sportuojančiaisiais (Perry, Williams, 1998). Mūsų tirtų paauglių sportinè patirtis menka, daugelis iš jų sportuoti pradejjo neseniai — tuo galima paaiškinti, kad lengvaja atletika užsiimantys paaugliai savo galimybę laimèti vertina iprastai.

S. M. Thuot ir kt. (1998) tyrimo duomenimis, nepriklausomai nuo lyties kognityviojo ir fizinio 


\begin{tabular}{|c|c|c|c|c|c|c|c|c|c|}
\hline \multirow{2}{*}{$\begin{array}{l}3 \text { lentelè. Tyrimo rezultatų } \\
\text { skirtumo patikimumas ly- } \\
\text { ties aspektu }\end{array}$} & \multirow{2}{*}{ Nerimo lygis } & \multicolumn{3}{|c|}{ Vaikinai } & \multicolumn{3}{|c|}{ Merginos } & \multirow{2}{*}{$\mathrm{p}$} & \multirow{2}{*}{$\alpha$} \\
\hline & & $\mathrm{F}$ & $\mathrm{E}$ & $\mathrm{K}$ & $\mathrm{F}$ & $\mathrm{E}$ & $\mathrm{K}$ & & \\
\hline \multirow{5}{*}{$\begin{array}{l}\text { Pastaba. Būsenos komponen- } \\
\text { tai: F - fizinis; E - emoci- } \\
\text { nis; K - kognityvusis. }\end{array}$} & Žemas & 1 & 3 & 1 & 1 & 0 & 2 & \multirow{5}{*}{0,019} & \multirow{5}{*}{$<0,05$} \\
\hline & Vidutinis, turịs tendenciją mažèti & 3 & 4 & 6 & 1 & 1 & 5 & & \\
\hline & Vidutinis, turịs tendenciją didèti & 1 & 2 & 10 & 0 & 3 & 11 & & \\
\hline & Aukštas & 0 & 2 & 2 & 0 & 0 & 1 & & \\
\hline & Labai aukštas & 0 & 0 & 0 & 0 & 0 & 0 & & \\
\hline
\end{tabular}

priešvaržybinès psichinès būsenos komponento ìvertinimas padidėdavo, pasitikejjimas sumažėdavo tuomet, kai jaunieji sportininkai susidurdavo su stipresniu varžovu. Dali šio teiginio galima patikrinti V. A. Aleksejevo metodikos klausimu, kaip intensyviai sportininkas galvoja apie savo varžovus. Kaip rodo tyrimo rezultatai (5 pav.), dauguma paaugliu sportininkų nepriklausomai nuo lyties teigia, kad apie savo varžovus galvoja kaip ir iprasta $(51,4 \%$ vaikinų ir 52\% merginu). Daugiau nei iprasta apie varžovus galvoja $31,4 \%$ vaikinu bei $36 \%$ merginų. Galvojančiu apie varžovus mažiau nei iprasta yra tik - 17,1\% vaikinų, 12\% merginų.

Manoma, kad priešvaržybinis nerimas gali sukelti begalę pojūčiu, kurie lemia sportininko pasirodymo varžybose kokybę. Šie pojūčiai skiriasi pasirinktos šakos, lyties ir patyrimo aspektais. Sporto psichologai, treneriai, noredami padeti sportininkui pasirodyti varžybose kuo geriau, turi atsižvelgti i vyraujanti psichinès būsenos prieš varžybas komponenta - fizinị, emocini ar kognityvuji. Jei sportininkui pavyks išlaikyti optimalią pusiausvyrą tarp psichinès būsenos prieš varžybas komponentų, jis galès mègautis sėkmingais pasirodymais varžybose.

Apibendrinus gautus rezultatus pagal abi metodikas (3 lent.), 95\% patikimumu (pasirinktas reikšmingumo lygis $\alpha=0,05$ ) nustatytas patikimas skirtumas lyties aspektu $\left(\chi^{2}=7,89 ; p=0,019\right)$.

Taigi tyrimo hipotezè, esą paauglių, užsiimančių lengvaja atletika, asmenybès nerimo lygio ir priešvaržybinès būsenos ypatumai skiriasi lyties aspektu pasitvirtina.

Šis tyrimas dar kartą patvirtino daugelio rezultatus, nors būta nerimo lygio prieš varžybas tyrimų, neaptikusių rezultatų skirtumo lyties aspektu (Lazarus, Folkman, 1984). Pastarieji tyrejjai pastebėjo, kad skirtingų lyčių tiriamieji nevienodai suvokdavo nerimo valdymo metodus prieš varžybas. V. Krane ir J. M. Williams (1994), atlikdami vieną iš priešvaržybinio nerimo tyrimų, patvirtino ryškų fizinio ir emocinio psichinès būsenos komponento, bet ne kognityviojo skirtumą tarp lyčių. Tokių rezultatu gauta ir mūsų tyrimo metu. Tyrejai
C. Madden ir kt. (1989) teigia, kad moterys mažina nerimą strategijomis, orientuotomis i emocijas, o vyrai tuo nesinaudoja. Tai galètu paaiškinti vaikinų emocinio priešvaržybinès psichinès būsenos komponento vyravimą, palyginti su merginų tuo pačiu komponentu. Kitų tyrimų duomenimis, moterys yra linkusios ieškoti socialinès paramos, nukreipti psichologinę pagalbą i emocijas (Hammermeister, Burton, 2004). Sporto psichologas ar treneris, norèdamas padèti sportininkui sumažinti nerimą, turi atsižvelgti į sportininko lytị. Tuo ịsitikinę minètieji autoriai, nes jų atliktas tyrimas parode, kad skirtingos lyties sportininkai naudojasi nevienodomis nerimo mažinimo poveikio priemonèmis.

\section{IŠVADOS}

1. Nagrinėjant jaunujų lengvaatlečių asmenybès nerimo lygiu tyrimo rezultatus, patikimo skirtumo tarp lyčių neaptikta $(p>0,05)$. Tarp paauglių merginų vyrauja vidutinis, turintis tendenciją didèti, nerimo lygis, o tarp paauglių vaikinu — vidutinis, turintis tendenciją didèti ir mažèti nerimo lygiai.

2. Ištyrus paauglių, užsiimančių lengvaja atletika, priešvaržybinès psichinès būsenos komponentus (fizini, emocini ir kognityvuji) nustatytas statistiškai patikimas skirtumas tarp merginų ir vaikinų priešvaržybinès psichinès būsenos $(\mathrm{p}<0,05)$. Tyrimo rezultatai parodè, kad nepriklausomai nuo lyties vyrauja kognityviojo (mintinio) psichinès būsenos komponento raiška. Psichinès būsenos emocinio komponento raiška yra didesnè tarp paauglių vaikinų negu tarp merginų. Fizinio komponento raiška tarp paaugliu — tiek vaikinu, tiek merginu — pasireiškia mažiausiai ir nepriklauso nuo lyties.

3. Lengvaja atletika užsiimančiu paauglių priešvaržybinès psichinès būsenos ir asmenybès nerimo raiškos tyrimo rezultatai, gauti įvertinus kiekvieno tiriamojo psichinę būseną individualiai pagal abi metodikas, statistiškai patikimai skiriasi lyties aspektu $(\mathrm{p}<0,05)$. 


\section{LITERATŪRA}

Barzinskienė, J. (1997). Krepšininkiu priešvaržybiniu būsenu ypatumai: magistro tezès. Kaunas: LKKI.

Bray, S. R., Jones, M. V., Owen, S. (2002). The influence of competition location on athletes' psychological states. Journal of Sport Behaviour, 25 (3), 231-242.

Bray, S. R., Martin, K. A., Widmeyer, W. N. (2000). The relationship between evaluative concerns and sport competition state anxiety among youth skiers. Journal of Sports Sciences, Vol. 18 (5), 353-361.

Gage, N. L., Berliner, D. C. (1994). Pedagogine psichologija. Vilnius: Alma Littera.

Gould, D., Petchlikoff, L., Weinberg, R. S. (1984). Antecedents of temporal changes in, and relationships between the CSAI-2 sub components. Journal of Sport Psychology, 6, 289-304.

Hall, H. K., Kerr, A. W. (1997). Motivational Antecedents of Precompetitive Anxiety in Youth Sport. The Sport Psychologist, Vol. 11 (6), 24-42.

Hammermeister, J., Burton, D. (2004). Gender Differences in Coping with Endurance Sport Stress: Are Men From Mars And Women From Venus? Journal of Sport Behavior, Vol. 27, Issue 2, 148-164.

Humara, M. (1999). The Relationship Between Anxiety and Performance: A Cognitive-Behavioral Perspective. The Athletic Insight Journal, Vol. 1, Issue 2. Prieiga per interneta:

$<$ http://www.athleticinsight.com/Vol1Iss2/Cognitive_Behavioral_Anxiety.htm>

Jankauskas, D. (2004). Streso kylančio prieš varžybas ypatumai: magistro tezès. Kaunas: LKKA.

Jurkšas, A. (2002). Lengvaatlečiu (metiku) psichologinio rengimo reikšme ju priešvaržybinèms būsenoms valdyti: magistro tezès. Kaunas: LKKA.

Kamal, A. F. et al. (1995). Self-esteem attributional components of athletes versus nonathletes. International Journal Sport Psychology, 26 (2), 189-195.

Kirby, R. J., Liu, J. (1999) Precompetition anxiety in Chinese athletes. Perceptual and Motor Skills, 88, 297303.

Krane, V., Williams, J. M. (1994). Cognitive anxiety, somatic anxiety, and confidence in track and field athletes: The impact of gender, competitive level and task characteristics. International Journal of Sport Psychology, 25, $205-217$.

Lazarus, R. S., Folkman, S. (1984). Stress, Appraisal, and Coping. New York: Springer.

Madden, C., Kirkby, R., McDonald, D. (1989). Coping styles of competitive middle distance runners. International Journal of Sport Psychology, 20, 287-296.

Marsh, H. W., Perry, C., Roche, L. (1995). Multidimensional self-concepts of elite athletes: How do they differ from the general population? Journal of Sport \& Exercise Psychology, 17 (1), 70-84.

Martens, R., Vealey, R. S., Burton, D. (1990). Competitive Anxiety in Sport. Champaign, IL: Human Kinetics.

Meyers, D. G. (2000). Psichologija. Kaunas: Poligrafija ir informatika.
Morris, I., Davis, M., Hutchings, D. (1981). Cognitive and emotional components of anxiety: Literature review and revised Worry. Emotionality Scale. Journal of Educational Psychology, 73 (4), 541-555.

Ommundsen, Y., Pedersen, B. H. (1999). The role of achievement goal orientations and perceived ability upon somatic and cognitive indices of sport competition trait anxiety. Scandinavian Journal of Medicine \& Science in Sports, Vol. 9 (6), 333-343.

Perry, J. D., Williams, J. M. (1998). Relationship of intensity and direction of competitive trait anxiety to skill level and gender in tennis. The Sport Psychologist, 12, $169-179$.

Schmolinsky, G. (2000). Track and Field: The East German Textbook of Athletics. Toronto: Sport Books Publisher.

Skučas, T. (2003). Didelio meistriškumo stalo tenisininku priešvaržybiniu būsenu ypatumai: magistro tezès. Kaunas: LKKA.

Sporto terminu žodynas. (2002). Parengè S. Stonkus. T. 1. Kaunas: LKKA.

Thuot, S. M., Kavouras, S. A., Kenefick, R. W. (1998). Effect of perceived ability, game location, and state anxiety on basketball performance. Journal of Sport Behavior, $21,311-321$.

Алексеев, В. А. (1995). Система подготовки спортсменов АГИМ. Москва: Физкультура и спорт.

Волков, И. П. (2002). Практикум по спортивной психологии. Санкт-Петербург.

Стамбулова, В. (1999). Психология спортивной карьеpы. Санкт-Петербург. 


\title{
PERSONAL AND PRE-COMPETITION ANXIETY PECULIARITIES OF TRACK-AND-FIELD ADOLESCENT ATHLETES
}

\author{
Skaistė Laskienė, Akvilė Gedvilaitė-Moan \\ Lithuanian Academy of Physical Education, Kaunas, Lithuania
}

\begin{abstract}
Pre-competition anxiety in sports is rather common not only among professional athletes, but also among adolescents who are active in sports, compete a lot and experience physical, emotional and social changes in their lives. The aim of the study was to evaluate track-and-field adolescent athletes' (12-18 years old) personal anxiety level and pre-competition anxiety. The hypothesis of the thesis was based on the assumption that adolescent track-and-field athletes' personal anxiety level and pre-competition anxiety components (somatic, emotional and cognitive) differ depending on gender.

Personal anxiety level was determined using J. Taylor's test. V. A. Alekseev's pre-competition anxiety test showed dominant competition state anxiety component among adolescent athletes.

Examination of the results and setting the personal anxiety level for the track-and-field adolescent athletes studied showed no gender differences $(p>0.05)$.

The findings of the results among track-and-field athletes' pre-competition anxiety components (somatic, emotional and cognitive) suggest dependable differences between adolescent girls and boys $(\mathrm{p}<0.05)$. The test results also showed that cognitive anxiety was most common in both groups, i.e. boys and girls.

The comparison of the results (those of both methods studied individually for every athlete) of the personal anxiety level and pre-competition anxiety tests from the perspective of gender suggested that the differences between gender do exist $(\mathrm{p}<0.05)$.

The tendency of inadequate pre-competition anxiety is harmful to an athlete. High levels of anxiety usually result in poor performance; therefore such athletes should be given special attention. Thus, the duty of a coach or a sport psychologist is to help an athlete to cope with the state of anxiety or make this kind of state less overwhelming, in order to achieve better performance.
\end{abstract}

Keywords: track-and-field athletics, personal anxiety, pre-competition anxiety.

Gauta 2007 m. balandžio 3 d.

Received on April 3, 2007

Priimta $2007 \mathrm{~m}$. birželio $13 \mathrm{~d}$.

Accepted on June 13, 2007
Skaistė Laskienè

Lietuvos kūno kultūros akademija

(Lithuanian Academy of Physical Education)

Sporto g. 6, LT-44221 Kaunas

Lietuva (Lithuanian)

Tel +37037302652

E-mails.laskiene@lkka.lt 